

\title{
EFFECT OF ECONOMY PRICING STRATEGY ON THE PROFITABILITY OF INSURANCE FIRMS IN KENYA.
}

\author{
${ }^{1 *}$ Perminus Kariuki Nyaga, \\ 1*Post Graduate Student,School of Business \\ Methodist University \\ *Corresponding Author's Email: kariopermi@gmail.com \\ ${ }^{2 *}$ Mr. Wilson Muema, \\ ${ }^{2 *}$ Lecturer,School of Business \\ Methodist University \\ *Corresponding Author's Email:
}

\begin{abstract}
Purpose: The objectives of the study were to establish the effect of economy pricing strategy on the profitability of insurance firms in Kenya

Methodology:The descriptive research design was preferred to other research designs because it reports the status of study variables. The population of study was the 45 insurance companies operating in Kenya as at $31^{\text {st }}$ December 2012. Data was drawn from a period of five (5) years that is $2008-2012$. The sample of this study was $10 \%$ of the sales workforce which comprised of 900 employees from the 45 insurance companies. The sample was generated by purposively sampling two employees from each insurance company. The researcher collected primary data with the help of a questionnaire. The primary data obtained from the questionnaires was summarized and analyzed by use of descriptive and inferential statistical techniques.

Results:Regression and correlation results indicated that there was a statistically significant and positive relationship between economy pricing strategies and profitability. These results implied that economy pricing has a positive effect on the profitability of insurance companies

Policy recommendation: The study recommends that insurance companies put in place measures assess the most effective pricing strategy to reduce product costs and thus increase profitability whenever such a strategy is used.
\end{abstract}

Keywords: economy pricing strategy,profitability 


\subsection{INTRODUCTION}

\subsection{Background of the study.}

Insurance industry, the world over forms an integral part of the financial services sector and plays a pivotal role in the economic growth of an economy. A well developed insurance market paves way for efficient resource allocation through transfer of risk and mobilization of savings. Insurance industry is well developed in economies such as the US, Europe, Japan, and South Korea. Emerging markets are found throughout Asia, specifically in India and China, and are also in Latin America. In 2012, the global insurance market is forecast to have a value of $\$ 4,608.5$ billion, an increase of $24.9 \%$ since 2007 . Life insurance dominates the global insurance market, accounting for $59.7 \%$ of the market's value (Andersen, 2008).

Insurance pricing, involves the calculation of each policy owner's fair share of losses and expenses. The price paid for insurance, called the premium, is the rate per unit or coverage multiplied by the number of unit purchased. Unit of insurance are measured differently according to the type of coverage. The rates are established before the exposure period to which they apply so that a forecast of the future must be made. The probable number and value of claims are forecast from historical loss experience with consideration given to trends and new developments. Insurers cannot set rates arbitrarily; rates are subject to state control (Andersen, 2008).

\subsection{Statement of the Problem}

Every firm is most concerned with its profitability. One of the most frequently used tools of financial ratio analysis is profitability ratios which are used to determine the company's bottom line. Profitability measures are important to company managers and owners alike. If a small business has outside investors who have put their own money into the company, the primary owner certainly has to show profitability to those equity investors. There has been a growing number of studies recently that test for measures and determinants of firm profitability. Financial industry's profitability has attracted scholarly attention in recent studies due to its importance in performance measurement (Kallhoefer\& Salem, 2008)

According to a study conducted by Ahmed et al (2011) on the determinants of performance, it indicated that size, risk and leverage are important determinants of performance of life insurance companies of Pakistan. According to Wright (1992) due to the unique accounting system used by life insurance companies, profitability of the industry has always been difficult to measure as compared with other financial institutions or corporations. Kasturi (2006) argued that the performance of insurance company in financial terms is normally expressed in net premium earned, profitability from underwriting activities, annual turnover, return on investment and return on equity. However, none of these studies focused on the effects of pricing strategies on the productivity of insurance companies in insurance firms in Kenya. If not properly implemented, pricing strategies adopted by the insurance industry are prone to fail and the more the reason for the study. 
International Journal of Finance And Accounting

ISSN xxxx-xxxx (Paper) ISSN 2518-4113 (Online)

Vol.2, Issue 6, No.4 pp 66 - 78, 2017

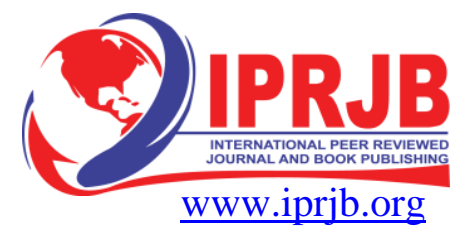

\subsection{Research Objectives}

i. To establish the effect of economy pricing strategy on the profitability of insurance firms in Kenya.

\subsection{LITERATURE REVIEW}

\subsection{Theoretical Orientation}

\subsubsection{The Weber-Fechner Law}

This law relates changes in a stimulus to the evolved response as follows:

$\mathrm{AS} / \mathrm{S}=\mathrm{k}$, where $\mathrm{S}$ is lie stimulus, AS is the "just noticeable difference" (i.e. so that $\mathrm{S}+\mathrm{AS}$ is perceived to be different from $S$ ), and $k$ is constant for each sensory stimulus. Fechner analyzed subjective sensations using differential increments and derived the Weber-Fechner law (Monroe, 1971).

Several authors have applied the Weber-Fechner law in the investigation of price thresholds Adam (1970), Gabor and Granger,(1966) and Monroe, (1973). The empirical evidence reported in these papers supports the hypothesis of upper and lower price thresholds and thus a range of prices which is considered acceptable. The Weber-Fechner law provides a means of experimentally determining such thresholds. Prices below the lower threshold are considered too low (quality is suspect) and prices above the upper threshold are considered too high. This was empirically demonstrated by Adam (Monroe, 1973).

The theory is relevant in this study as it is used to explain how perception of prices by consumers affects them in purchasing insurance products. The more the consumers perceive those prices positively the more sales they make hence aiding in making the pricing decisions of the firms specially understanding the threshold of prices of such strategies.

\subsection{Empirical Literature Review}

\subsubsection{Economy Pricing Strategy and Profitability of Insurance Firms}

Ekundayo, (2012) found that in order to meet specific objectives, and within the content of factors that influence pricing decision, firms have to adopt some type of economy pricing strategy. For example, a construction firm that is targeting a particular construction market could do this by tendering for such jobs at a low price level. Fellows and Langford, (2000) suggest that firms may adopt low profit level pricing in times of economic recession in order to maintain market share or to penetrate a new market. Skitmore, (2007) also has investigated economy oriented pricing strategies of construction firms submitting bid prices aimed at what the market will bear. 
International Journal of Finance And Accounting

ISSN xxxx-xxxx (Paper) ISSN 2518-4113 (Online)

Vol.2, Issue 6, No.4 pp 66 - 78, 2017

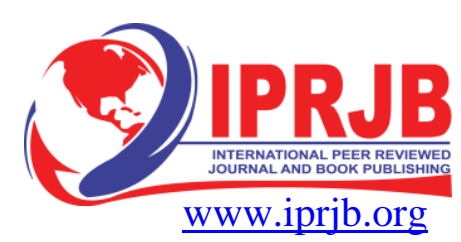

\subsection{Conceptual Framework}

Independent variables $\quad$ Dependent Variable

Economy Pricing Strategy

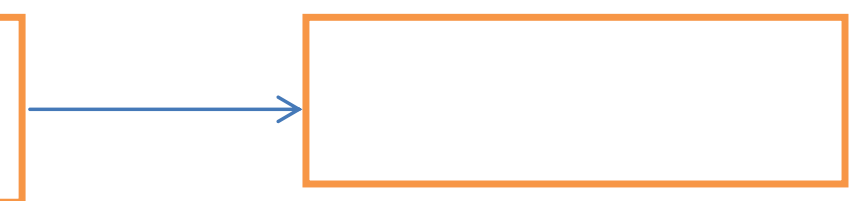

Source: Figure 1: Conceptual Model Researcher (2013)

\subsection{METHODOLOGY}

The descriptive research design was preferred to other research designs because it reports the status of study variables. The population of study was the 45 insurance companies operating in Kenya as at $31^{\text {st }}$ December 2012. Data was drawn from a period of five (5) years that is 20082012. The sample of this study was $10 \%$ of the sales workforce which comprised of 900 employees from the 45 insurance companies. The sample was generated by purposively sampling two employees from each insurance company. The researcher collected primary data with the help of a questionnaire. The primary data obtained from the questionnaires was summarized and analyzed by use of descriptive and inferential statistical techniques.

\subsection{RESULTS FINDINGS}

\subsection{Quantitative Data Analysis}

This section presented the variables and their effect on profitability of insurance companies.

\subsubsection{Economy Pricing Strategy and Profitability of Insurance Companies in Kenya}

The study sought to establish the effect of economy pricing strategy on the profitability of insurance companies. The results were presented in Table 4.7.Seventy five percent of the respondents agreed that there had been an increase in use of the economy pricing strategy in their firm in the recent years. Above eighty two percent $(82.8 \%$ ) agreed that there had been an increase in sales of their products as a result of economy pricing strategy. Ninety two point two percent of the respondents agreed on the statement that their company has been in a position to reduce product costs whenever economy pricing of its products was used. Eighty six percent agreed that most of their competitor firms have failed to effectively adopt economy pricing strategies giving them a competitive edge over them. Above seventy nine percent $(79.7 \%)$ agreed that the measures put in place to implement our economy pricing strategies were better compared to competitor firms. The overall likert mean was 3.88 with a standard deviation of 0.86 and this implies that economy pricing greatly influences the profitability of insurance companies.

These findings agree with those of Irwin and Klenow, (2004) who found that the potential detrimental effects to both firms when the firm's economy product pricing rating improves are a direct result of both firms' complete flexibility in adjusting their prices in response to changes to product ratings. They also agree with those of Flanagan and Norman (2006) who examined the economy pricing strategies adopted manufacturing firms and concluded that they resulted in significant effect on profitability. 
Table 1: Economy Pricing Strategy and Profitability of Insurance Companies

\begin{tabular}{|c|c|c|c|c|c|c|c|}
\hline Statement & $\begin{array}{l}\text { Strongl } \\
\mathbf{y} \\
\text { Disagre } \\
\mathbf{e} \\
\end{array}$ & $\begin{array}{c}\text { Disagre } \\
\text { e }\end{array}$ & Neutral & Agree & $\begin{array}{l}\text { Strongl } \\
\text { y Agree }\end{array}$ & Mean & $\begin{array}{l}\text { Std. } \\
\text { Devia } \\
\text { tion }\end{array}$ \\
\hline $\begin{array}{l}\text { There has been an increase in } \\
\text { use of the economy pricing } \\
\text { strategy in our firm in the recent } \\
\text { years }\end{array}$ & $1.60 \%$ & $14.10 \%$ & $9.40 \%$ & $62.50 \%$ & $12.50 \%$ & 3.7 & 0.92 \\
\hline $\begin{array}{l}\text { There has been an increase in } \\
\text { sales of our products as a result } \\
\text { of economy pricing strategy }\end{array}$ & $3.10 \%$ & $3.10 \%$ & $10.90 \%$ & $67.20 \%$ & $15.60 \%$ & 3.89 & 0.82 \\
\hline $\begin{array}{l}\text { Our company has been in a } \\
\text { position to reduce product costs } \\
\text { whenever economy pricing of its } \\
\text { products is used }\end{array}$ & $4.70 \%$ & $3.10 \%$ & $0.00 \%$ & $75.00 \%$ & $17.20 \%$ & 3.97 & 0.85 \\
\hline $\begin{array}{l}\text { Most of the competitor firms } \\
\text { have failed to effectively adopt } \\
\text { economy pricing strategies } \\
\text { giving us a competitive edge } \\
\text { over them }\end{array}$ & $4.70 \%$ & $4.70 \%$ & $4.70 \%$ & $67.20 \%$ & $18.80 \%$ & 3.91 & 0.92 \\
\hline $\begin{array}{l}\text { The measures put in place to } \\
\text { implement our economy pricing } \\
\text { strategies are better compared to } \\
\text { competitor firms }\end{array}$ & $0.00 \%$ & $7.80 \%$ & $12.50 \%$ & $60.90 \%$ & $18.80 \%$ & 3.91 & 0.79 \\
\hline Average & & & & & & 3.88 & 0.86 \\
\hline
\end{tabular}

\subsection{Pearson's Correlation Analysis}

Bivariate correlation indicates the relationship between two variables. It ranges from 1 to -1 where 1 indicates a strong positive correlation and a -1 indicates a strong negative correlation and a zero indicates lack of relationship between the two variables. The closer the correlation tends to zero the weaker it becomes. The correlation between profitability and economy pricing strategy was strong and positive (0.706) and was statistically significant (0.000). The correlation between profitability and skimming was also strong and positive (0.693) and was statistically significant (0.000). The correlation between profitability and penetration, premium and price optimization strategies was strong and positive $(0.688,0.522$, and 0.644 respectively). All the three variables were statistically significant as they each had a significance level of 0.000 .

Table 2 Pearson's Correlation Analysis

\begin{tabular}{llcc}
\hline & & ROA & Economy \\
\hline \multirow{2}{*}{ ROA } & Pearson & & \\
& Correlation & 1.000 \\
& Sig. (2-tailed) & &
\end{tabular}


International Journal of Finance And Accounting

ISSN xxxx-xxxx (Paper) ISSN 2518-4113 (Online)

Vol.2, Issue 6, No.4 pp 66 - 78, 2017

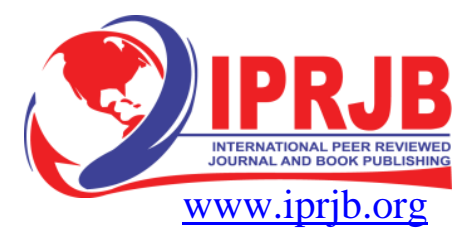

\begin{tabular}{llll} 
& Pearson & & \\
Economy & Correlation & 0.706 & 1.000 \\
& Sig. (2-tailed) & 0.000 & \\
\hline
\end{tabular}

\subsection{Regression Analysis}

Table 3 below shows the fitness of the regression model in explaining the variables under study. The results indicate that the variables; economy pricing, were satisfactorily explaining profitability. This conclusion is supported by the $\mathrm{R}$ square of 0.651 . This further means that the independent variables can explain $65.1 \%$ of the independent variable (profitability).

Table 3 Model Fitness

\begin{tabular}{lc}
\hline Indicator & Coefficient \\
\hline $\mathrm{R}$ & 0.807 \\
R Square & 0.651 \\
Adjusted R Square & 0.620 \\
Std. Error of the Estimate & 0.0778 \\
\hline
\end{tabular}

\subsection{Analysis of Variance}

ANOVA statistics presented on Table 4indicate that the overall model was statistically significant. This was supported by a probability ( $p$ ) value of 0.000 . The reported $p$ value was less than the conventional probability of 0.05 significance levels thus its significance in the study. These results indicate that the independent variables are good predictors of performance in terms of profitability.

The findings led to rejection of null hypothesis that economy pricing, did not significantly contributeto financial performance of insurance companies.

Table 5 Analysis of Variance

\begin{tabular}{llccccc}
\hline Model & & Sum of Squares & df & Mean Square & F & Sig. \\
\hline & Regression & 0.653 & 5 & 0.131 & 21.596 & 0.000 \\
& Residual & 0.351 & 58 & 0.006 & & \\
& Total & 1.004 & 63 & & & \\
\hline
\end{tabular}

Regression of coefficients results in Table 4.16 shows that there is a positive relationship between profitability and economy pricing, s and whose beta coefficients are 0.069. The results indicate that; an increase in the economy pricing strategies by one unit leads to an increase in profitability by 0.069 units;

Table 6 Regression of Coefficients

\begin{tabular}{lcccc}
\hline & B & Std. Error & t & Sig. \\
\hline (Constant) & -0.551 & 0.075 & -7.390 & 0.000 \\
Economy & 0.069 & 0.017 & 4.018 & 0.000 \\
\hline
\end{tabular}

\subsection{Summary Equations}

The summary equation was; 


\section{$\mathrm{ROA}=-\mathbf{0 . 5 5 1}+\mathbf{0 . 0 6 9}$ Economy pricing}

\subsection{SUMMARY OF FINDINGS, CONCLUSIONS AND RECOMMENDATIONS}

\subsection{Summary of study}

This section attempted to summarize the findings that were obtained in chapter four.

\subsubsection{Economy Pricing Strategy and Profitability of Insurance Companies}

The descriptive statistics indicated that majority of the respondents agreed that there had been an increase in use of the economy pricing strategy in their firm in the recent years, there had been an increase in sales of their products as a result of economy pricing strategy, their company has been in a position to reduce product costs whenever economy pricing of its products was used, most of the competitor firms had failed to effectively adopt economy pricing strategies giving them a competitive edge over them and the measures put in place to implement them economy pricing strategies are better compared to competitor firms. Regression and correlation results indicated that there was a statistically significant and positive relationship between economy pricing strategies and profitability. These results implied that economy pricing has a positive effect on the profitability of insurance companies. The findings agree with those of Flanagan and Norman (2006) who examined the economy pricing strategies adopted manufacturing firms and concluded that they resulted in significant effect on profitability.

\subsection{Conclusion}

Based on the objectives and the findings of the study the following conclusion can be made; From the study it can be concluded that the insurance companies had put in place effective economy pricing measures as firms had ensured reduction of product costs giving them a competitive edge over their rivals. It can also be concluded that economy pricing was a strong determinant of insurance company's profitability.

\subsection{Recommendations}

\subsubsection{Recommendations for study findings}

The study recommends that insurance companies put in place measures assess the most effective pricing strategy to reduce product costs and thus increase profitability whenever such a strategy is used. They should also adopt ways to implement their pricing strategies better compared to competitor firms. They should also ensure that the strategies they adopt help them discourage competition and focus more on both acceptance and profits. They should also use strategies that positively influence consumer's perception through fair pricing in setting their product prices so that customers will be satisfied when paying for such services.

\subsubsection{Recommendations for Further Research}

This study was not exhaustive by any means and therefore it is suggested that another study be conducted in the insurance industry in probably using the same variables so as to establish whether the findings of this study will hold true for individual products since the risk rating is different from one product to another with special focus on Medical and Motor private classes which have been reported as loss making by many firms. An additional research can be done to find out exactly the reason for bad performance of these classes. 
International Journal of Finance And Accounting

ISSN xxxx-xxxx (Paper) ISSN 2518-4113 (Online)

Vol.2, Issue 6, No.4 pp 66 - 78, 2017

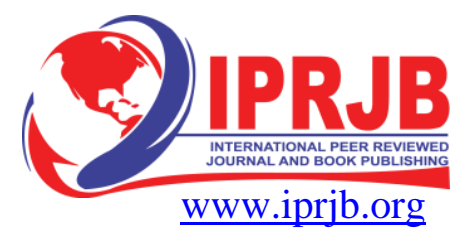

\section{REFERENCES}

Adam, D. (1970).Consumer Reactions to Price, in B. Taylor and G. Wills, eds., Pricing Strategy, (Brandon Systems Press, Princeton, New Jersey), 75-88.

Ahmed, N., Zulfqar, A. \&Ahmad, U. (2011). Determinants of Performance: A Case of life Insurance Sector of Pakistan International Research Journal of Finance and Economics ISSN 1450-2887 Issue 61 (2011).

Akerlof, G. (1970).The Market for Lemons. Quarterly Journal of Economics 84 : 488-500.

Andersen,T. J. (2008h).The Performance Relationship of effective Risk Management: Exploring the firm-specific investment Rationale. Long Range Planning 4(12) 155-176

Bain, J.S. (2001).Relation of Profit Rate to Industry concentration: American manufacturing, 1936 - 1940, Quarterly Journal of Economics, 65: 293-324.

Bain, J.S.(1996).Barriers to New Competition, Their Character and Consequences in Manufacturing Industries (Cambridge, MA: Harvard University Press).

Bajtelsmit, V. L.\&Bouzouita, R. (1998).Profit and Concentration in Commercial Automobile Insurance Lines .Journal of Insurance Issues 21(2) 175-182

Besanko, D. \&Wayne, L. W. (2000).Optimal Price Skimming by a Monopolist Facing Rational Consumers.Management Science 36 (5):555-567.

Bhattacharya U. \&Dittmar,A (2001).Costless Versus Costly Signaling: Theory and Evidence from Share Repurchase working paper, Kelley School of Business, University of Indiana, 2001.

Black, F.\& Scholes, M. (1973). The Pricing of Options and Corporate Liabilities.Journal of Political Economy 81,637-654.

Breedon, D.T. (1979). An lntertemporal Asset Pricing Model with Stochastic Investment and Consumption Opportunities.Journal of Financial Economics 6, 273-296. 
International Journal of Finance And Accounting

ISSN xxxx-xxxx (Paper) ISSN 2518-4113 (Online)

Vol.2, Issue 6, No.4 pp 66 - 78, 2017

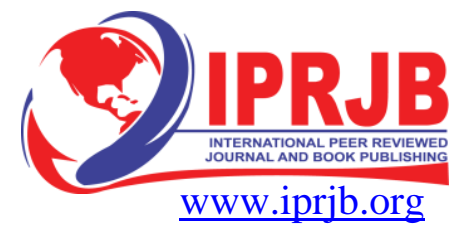

Matt, C.1., Richtel, M.\& Andrew, R. S. (2004).At\&T Wireless for Sale as a Shakeout Starts. New York Times, Jan 21,

Chandran, E. (2004).Research Methods; A quantitative approach with Illustration. From Christian Ministries: Nairobi Daystar University

Cooper, D.R. \& Schindler, P.S. (2008).Business Research Methods, 10th Edition, New York, McGraw-Hill, 183.

Cox, J. D. and Rubinstein, M. (1985) .Options Markets. (Englewood Cliffs, N.J.: Prentice-Hall).

Cummins, J. D (1988a).Risk-Based Premiums for Insurance Guaranty Funds. Journal of Finance $43,823-839$.

Cummins, J. D. (1988b) Capital Structure and Fair Profits in Property-Liability Insurance, working paper, University of Pennsylvania

Ekundayo, O.A. (2012). The Impact of Risk Pricing on Profit Maximization of Insurance Companies, International Journal of Academic Research in Economics and Management Sciences Vol. 1, No. 4 ISSN: 2226-3624 21

Emory, F. (1970).Some Psychological Aspects of Price, in B. Taylor and G. Wilbro, eds., Pricing Strategy, (Brandon Systems Press, Princeton, New Jersey), 98-1 11.

Flanagan, R. and Norman, G. (2006).Pricing Policy, in Hillebrandt, P.M. and Cannon J. (eds), The Management of Construction Firms - Aspect of Theory, Macmillan, pp. 129-153

Fornell, C., Michael D. J., Eugene W. A., Jaesung, C. and Barbara E. B. (1999).The American Customer Satisfaction Index: Nature, Purpose, and Findings. Journal of Marketing 60 (4):7-18.

Gabor, A. and Granger,C. (1966).Price as an Indicator of Quality: Report on an Inquiry, Economica 33, 43-70.

Harris, M. and Raviv, A. (1985).A Sequential Signaling Model of Convertible Debt Call Policy." the Journal of Finance 40(5): 1263-1281. 
International Journal of Finance And Accounting

ISSN xxxx-xxxx (Paper) ISSN 2518-4113 (Online)

Vol.2, Issue 6, No.4 pp 66 - 78, 2017

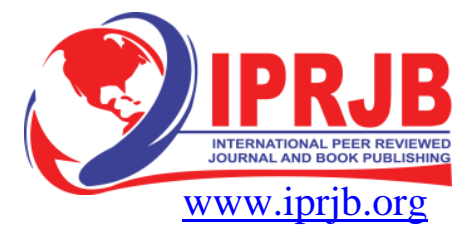

Heinkel, R. A(1982). Theory of Capital Structure Relevance under Imperfect Information the Journal of Finance 37 (5) 1141-1150.

Helson, H. (1964).Adaptation-Level Theory, (Haver and Row, New York, NY).

Hifza, M. (2011).Determinants of Insurance Companies Profitability: An Analysis of Insurance Sector of Pakistan, Academic Research International, Volume 1, Issue 3

Irwin, D. A.\& Peter, J. K. (2004). Learning-by- Doing Spillovers in the Semiconductor Industry.Journal of Political Economy 102:1200-1227.

Jarrow, R. (1988).Finance Theory (Englewood Cliffs, N J: Prentice-Hall).

Joskow, P. (2003). Cartels, Competition and Regulation in the Property-Liability Insurance Industry, Bell Journal of Economic and Management Science, 4(2), 375-427

Kahneinann, T. and Tversky,C. (1979).Prospect Theory: an Analysis of Decision Under Risk, Econometrica 47, 263-291.

Kallhoefer, R. and Salem, C. (2008).Profitability Analysis in the Egyptian Banking Sector.

Kasturi, R. (2006).Performance Management in Insurance Corporation .Journal of Business Administration online 5 (1)

Kennon, J. (2013). Return on Assets (ROA) Investing Lesson 4 - Analyzing an Income Statement. Retrieved from http: // beginnersinvest.about.com / od/ income statement analysis /a / return-on-assets-roa-income-statement.htm

Kerlinger, F. (1964).Foundations of behavioural research. New York: Holt.

Leland, H.E. and Pyle D.H. (1977) .Information Asymmetries, Financial Structure, andFinancial Intermediation.The Journal of Finance 32(2) : 371-387.

Markowitz, H. M. (1952).Portfolio Selection.The Journal of Finance.Vol 13(1) 
International Journal of Finance And Accounting

ISSN xxxx-xxxx (Paper) ISSN 2518-4113 (Online)

Vol.2, Issue 6, No.4 pp 66 - 78, 2017

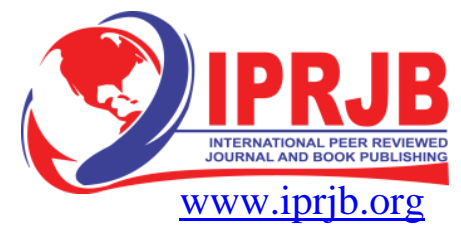

Merton, R. C. (1973a).Theory of Rational Option Pricing.Bell Journal of Economics and Management Science 4, 141-183.

Merton, R. C. (1973b).An Intertemporal Capital Asset Pricing Model.Econometrica 41, 867-880.

Monroe, K. B. (1971).Measuring Price Thresholds by Psychophysics and Latitudes ofAcceptance, Journal of Marketing Research 8, November, 460-464

Mugenda, O. \&Mugenda, A. (1992).Research methods: Quantitative and qualitative approaches. Nairobi: Act press, 42-48.

Mugenda, O. M. and Mugenda, A. G. (2003).Research Methods: Quantitative and Qualitative Approaches, Acts Press, Nairobi-Kenya

Nehaus, G. R. and Harringhton, S. G. (2003).Risk Management and Insurance. Singapore, McGraw Hill/ Irwin Pub.

Nguyen, K. M. (2006).Financial Management and Profitability of Small and Medium Enterprises. Southern Cross University Thesis Submitted to the Graduate College of Management in partial fulfillment of requirements for the degree of Doctor of business. Administration. Paper Provided by the German University in Cairo Working Paper Series.

Niedrich, R W., Subhash, S. and Douglas, H. W. (2001) .Reference Price and Price Perceptions: a Comparison of Alternative Models, Journal of Consumer Research 28,

Parkin, M. (2003).Microeconomics, Addison Wesley, Boston.

Pass, C., Lowers, B. and Davies, L. (2000).Economics, Harper Collins Publishers, London.

Poitevin, M. (1989).Financial Signaling and the Deep-Pocket Argument.The Rand Journal of Economics 20(1) 26-40.

Putler, Daniel S., (1992).Incorporating Reference Price Effects into a Theory of Consumer Choice, Marketing Science 11, 3 , 287-309 
International Journal of Finance And Accounting

ISSN xxxx-xxxx (Paper) ISSN 2518-4113 (Online)

Vol.2, Issue 6, No.4 pp 66 - 78, 2017

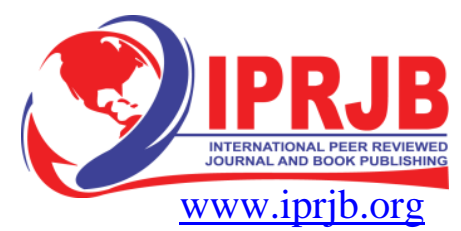

Rebao, C. and Ann, W. (2004) .Determinants of Financial Health of Asian Insurance Companies, the Journal of Risk and Insurance Volume 71 Number 3.

Richtel, M. and Andrew R. S. (2004).At\&T Wireless for Sale as a Shakeout Starts.New York Times, Jan 21, 2004, C1.

Robinson, B. and Chet, L. (2005).Dynamic Price Models for New-Product Planning.Management Science 21 (10):1113-1122.

Ross, S.A. (1977) .Determination of Financial Structure: the Incentive-Signaling Approach. The Bell Journal of Economics 8 (1977): 23-40.

Sekaran, U. \&Bougie, R. (2010).Research Methods for Business :A Skill Building Approach. $5^{\text {th }}$ Edition.Aggarwal printing press, Delhi, ISBN: 978-81-265-3131-8

Sherif, M. and Horland, C (1961) .Social Judgment, (Yale University Press. New Haven,NY \)

Skitmore, R. A. (2007).Risk, Return, and Arbitrage, in I. Friend and J. Bicksler, eds., Risk and Return in Finance, v.I. (Cambridge, MA: Ballinger Publishing Co.)

Spence, M. (1973).Job Market Signaling.The Quarterly Journal of Economics 87(3) 1355-374.

Stigler, G. L. (2004).A Theory of Oligopoly, Journal of Political Economy, 17(1): 69-8

Szymanski, D. M. and David H. H. (2001).Customer Satisfaction: A Meta-Analysis of the Empirical Evidence.Journal of the Academy of Marketing Science 29 (1):16-35.

Talmor, E. (1981).Asymmetric Information, Signaling, and Optimal Corporate FinancialDecisions" Journal of Financial and Quantitative Analysis 16(4) 413-435

Varki, S. and Mark, C. (2001).The Role of Price Perceptions in an Integrated Model of Behavioral Intentions.Journal of Service Research 3 (3):232-240.

Voss, G. B., Parasuraman, A. \&Dhruv G. (1998).The Roles of Price, Performance, and Expectations in Determining Satisfaction in Service Exchanges. Journal of Marketing 62 (4):46-61. 
International Journal of Finance And Accounting

ISSN xxxx-xxxx (Paper) ISSN 2518-4113 (Online)

Vol.2, Issue 6, No.4 pp 66 - 78, 2017

Winer, Russell S. (1988).Behavioral Perspectives on Pricing: Buyers' Subjective Perceptions of Price Revisited, in Devinney, T. M., ed., Issues in Pricing: Theory and Research, (Lexington Books, Lexington, MA), Chapter 